Boise State University

ScholarWorks

Educational Technology Faculty Publications and

Presentations

Department of Educational Technology

8-1-2017

In Search of a Better Understanding of Social Presence: An Investigation into How Researchers Define Social Presence

Patrick R. Lowenthal

Boise State University

Chareen Snelson

Boise State University 
This is an author-produced, peer-reviewed version of this article. The final, definitive version of this document can be found online at Distance

Education, published by Routledge. Copyright restrictions may apply. doi: 10.1080/01587919.2017.1324727

\title{
In Search of a Better Understanding of Social Presence: An Investigation into How Researchers Define Social Presence
}

\author{
Patrick R. Lowenthal \\ Boise State University \\ and \\ Chareen Snelson \\ Boise State University
}

\begin{abstract}
Research on social presence and online learning continues to grow. But to date, researchers continue to define and conceptualize social presence very differently. For instance, at a basic level, some conceptualize social presence as one of three presences within a Community of Inquiry, while others do not. Given this problem, we analyzed how researchers in highly cited social presence research defined social presence in an effort to better understand how they are defining social presence and how this might be changing over time. In this article, we report the results of our inquiry and conclude with implications for future research and practice.
\end{abstract}

Keywords: social presence, immediacy, intimacy, community, connection, definitions, online learning, online teaching, community of inquiry, collaboration

Social presence is a popular construct used to understand how people socially interact in online learning environments (Whiteside, Dikkers, \& Swan, 2017). However, despite the prevalence with which it is discussed in research, educational researchers continue to define social presence differently (Kawachi, 2013; Kehrwald, 2008; Kreijns, Van Acker, Vermeulen, \& Van Buuren, 2014; Lim \& Richardson, 2016; Sung \& Mayer, 2012). For example, some researchers define social presence in terms of being a "real" person, whereas others define it in terms of feeling a connection or sense of belonging with others. Differences like these are problematic because researchers end up investigating related but different constructs (see Kreijns, Kirschner, Jochems, van Buuren, 2011). To investigate this problem further and to better understand differences among commonly used definitions of social presence, we analyzed how researchers of highly cited research defined social presence. In this article, we describe the problem in more detail and then report on the results of our inquiry, discuss the findings, and conclude with implications for future research and practice.

\section{Background}

Social presence theory was developed by Short, Williams, and Christie (1976) in the 1970s to explain how media affect communication. They were specifically interested in how telecommunications influenced how people communicate. Short et al. (1976) described social presence theory, along with research conducted on media effects that informed the theory, and other related theories and research in their book, The Social Psychology of Telecommunications. In their book, Short et al. (1976) defined social presence as the "degree of salience of the other person in the interaction and the consequent salience of the interpersonal relationships" (p. 65); in other words, they conceptualized social presence as the degree to which a person perceives another person (or persons) as being salient when communicating. They conceptualized social presence primarily as a quality of a communication medium. They argued that communication media differ in their degree of social presence and that these differences influence how people communicate. Short et al. thought that people perceive some media as having a higher degree of social presence (e.g., video) than other media (e.g., audio); they also believed that media with a high degree of social presence are perceived as sociable, warm, and personal, whereas media with a low degree of social presence are perceived as less personal. Short et al. also found that social presence was influenced by such things as one's apparent distance (i.e., sense of being "there”) and realness (p. 74). 
This is an author-produced, peer-reviewed version of this article. The final, definitive version of this document can be found online at Distance Education, published by Routledge. Copyright restrictions may apply. doi: 10.1080/01587919.2017.1324727

In the 1980s, researchers began studying the effects that text-based asynchronous computer-mediated communication (CMC), like email, had on communication in the workplace. Most researchers at this time came to the conclusion that CMC was an inherently antisocial and impersonal communication medium (Walther, 1996; Walther, Anderson, \& Park, 1994). Many of these researchers used social presence theory, or other cues-filtered out theories, to situate and inform their findings. They argued that CMC was a lean medium, lacking the nonverbal and relational cues common in face-to-face communication. Due to the absence of nonverbal and relational cues, researchers concluded that CMC was better suited for task-oriented communication than interpersonal-oriented communication (Walther \& Parks, 2002).

During the 1990s, as people gained more experience using text-based asynchronous CMC, many began to question the technologically deterministic perspective that CMC was inherently an antisocial and impersonal medium. Walther (1992) even argued that people are social by nature and that given enough time, people would find ways to socially interact, even with text-based asynchronous CMC. Further, as educators gained more experience using CMC (e.g., web-based bulletin boards and email) in educational settings—settings that rely heavily on social interaction - they found that even without nonverbal cues, people were able to establish themselves as "real" people and therefore use the communication medium socially (Gunawardena, 1995; Gunawardena \& Zittle, 1997). In fact, Gunawardena (1995) argued that:

research on social presence and CMC has indicated that despite the low social bandwidth of the medium, users of computer networks are able to project their identities whether "real" or "pseudo," feel the presence of others online, and create communities with commonly agreed on conventions and norms that bind them together to explore issues of common interest. (p. 156)

Building upon the belief that CMC can support social interaction and that education is inherently a social activity, during the late 1990s Garrison and his colleagues popularized the concept of social presence by including it as one of three key types of presence in their Community of Inquiry (CoI) framework. Garrison et al. (2000) posited that a meaningful educational experience occurs in a community comprised of teachers and students through the interaction of social presence, teaching presence, and cognitive presence. Garrison et al. (2000), having moved past the technologically deterministic perspective of CMC, were interested in both how to use computer conferences for educational purposes and how to identify each of the three presences in the CoI framework within computer conferences. As such, their definition of social presence as "the ability of learners to project themselves socially and affectively into a community of inquiry” (Rourke et al., 1999, p. 50) was likely influenced by their research goals.

The Community of Inquiry framework remains one of the most popular frameworks for online learning. As of March 2017, Garrison, Anderson, and Archer's (2000) original CoI article had been cited over 3,900 times according to Google Scholar (see goo.gl/raxVbv). Despite its popularity, it is important to remember that the CoI framework still has its critics-most of whom, question whether social presence is essential for a meaningful educational experience (see Annand, 2011; Rourke \& Kanuka, 2009; Xin, 2012) —and that research continues to be conducted on social presence and online learning that is not grounded in the CoI framework.

How people think about, talk about, and research social presence has changed a bit over the years. For instance, in a general sense, social presence began as a quality of a communication medium but was reconceptualized as being more dependent on the behaviors one uses (e.g., immediacy behaviors) and/or the degree to which one perceives another person(s) as being "real" and "there" when using a communication medium (e.g., CMC). Whether conceptualized as a part of a CoI or not, social presence remains a central construct in online learning (Whiteside, Dikkers, \& Swan, 2017). We posit, though, that once one takes a closer look at how people write about social presence, they will see less consensus among the definitions they use.

Over the past few years, the first author has argued that definitions of social presence tend to fall on a continuum (see Lowenthal, 2009, 2012). On one side, there are definitions that take a less emotional understanding of being "real" and "there." These definitions tend to interpret being "real" simply in terms of whether one senses that he or she is talking to a human being and not a machine; they also tend to interpret being "there" in terms of whether one senses that the other person(s) they are talking to is present and actively engaged. On the other end of the continuum are definitions that tend to interpret being "real" and "there" in more emotional terms. These definitions tend to interpret being "real" 
This is an author-produced, peer-reviewed version of this article. The final, definitive version of this document can be found online at Distance Education, published by Routledge. Copyright restrictions may apply. doi: 10.1080/01587919.2017.1324727

in terms of understanding what makes a person unique or authentic (e.g., in terms of identity, personality, persona etc...); they also tend to interpret being "there" in terms of whether another person(s) is present in a supportive and caring sense.

While useful in a broad sense, this explanation oversimplifies how researchers define and in turn understand social presence. For instance, scholars might think of being "real" in an emotional sense but being "there" in a less emotional sense (see Kehrwald, 2008). Further, and perhaps more importantly, is that this explanation fails to take into consideration all of the other ways that researchers think about social presence. For instance, some researchers think of social presence in terms of one-to-one communication, while others conceptualize it as one-to-many or many-tomany; some researchers think about social presence in terms of behaviors one projects, while others think about social presence in terms of the perceptions one has of others when communicating; still others talk about social presence in terms of connecting or even belonging. To illustrate this point, Table 1 lists five different definitions of social presence used by online researchers - only one of which conceptualized social presence terms of a community of inquiry. Given complexities like these, we set forth to better understand how researchers define social presence.

Table 1

Examples of Social Presence Definitions

\section{Selected Definitions}

Being there

“the degree of salience (i.e., quality or state of "being there”) between two communicators” (Dunlap \& Lowenthal, 2009)

\section{Being real}

"The degree to which a person is perceived as "real” in mediated communication" (Gunawardena \& Zittle, 1997)

\section{Projecting}

"the ability of learners to project themselves socially and affectively into a community of inquiry" (Rourke et al., 1999)

\section{Connecting}

“The degree of feeling, perception, and reaction of being connected on CMC to another intellectual entity” (Tu, 2002)

\section{Belonging}

"A student's sense of being in and belonging in a course and the ability to interact with other students and an instructor” (Picciano, 2002)

\section{Method}

Given the overall popularity of social presence - and yet various ways researchers define it —we investigated how researchers, in highly cited articles, defined social presence. The goal of this exploratory study was to better understand just how differently highly cited researchers defined social presence. The following research questions guided our study:

- Research Question 1: How do researchers define social presence in highly cited social presence research?

- Research Question 2: How prevalent is the Community of Inquiry framework in highly cited social presence research?

- Research Question 3: How have highly cited researchers changed their definition over time? 
This is an author-produced, peer-reviewed version of this article. The final, definitive version of this document can be found online at Distance Education, published by Routledge. Copyright restrictions may apply. doi: 10.1080/01587919.2017.1324727

To answer these questions, we used Google Scholar to identify the top 50 cited articles or book chapters using the search terms "social presence." We chose to use Google Scholar because we wanted a comprehensive, yet easily accessible, way to identify highly cited scholarship. It is important to note that we use the term "research" and "researcher" in a general sense throughout this article; for the purposes of this study, we were interested in highly cited scholarship, whether that be primary empirical research or other types of scholarship (e.g., literature reviews).

We downloaded a copy of each article and noted how the researcher(s) defined social presence. One researcher initially coded the definitions we identified in each article. The researcher began with some predetermined codes based on the literature-specifically, "being there," "being real," "connection,” "belonging” (see Lowenthal, 2009 2012, Lowenthal \& Dunlap, 2014) — and then, using an open coding approach, added additional codes as they emerged from the data. However, after the initial analysis, we noticed that the search terms "social presence" identified articles that focused on "social presence" in other contexts (e.g., gaming or online shopping). While there are benefits of thinking about social presence in other contexts, we were interested in learning more about how researchers of online learning in particular think about and write about social presence. Thus, we conducted a second search on Google Scholar, using the search terms "social presence," but we immediately removed articles (22 in all) that did not focus on social presence and online learning; we ended up searching the first ten pages of Google Scholar to ensure we had identified all highly cited articles or book chapters on social presence and online learning (see the Appendix for a list of the articles and book chapters included in the final analysis). This time, a second researcher coded the definitions using the codes previously generated from the first analysis. After the initial analysis, weeks later, the researcher double-checked his coding by recoding each definition to ensure consistency.

This study, like all studies, has its limitations. First, in a few cases we determined that either the researcher(s) did not clearly define social presence or that the researcher(s) defined it in more than one way (e.g., by citing two or more different definitions from previous literature). Second, we intentionally narrowed the scope of our inquiry to highly cited articles and only those which focused on online learning. The possible issue with this approach is that it might only present the dominant perspective of how researchers of online learning define social presence and one that is highly influenced by the Community of Inquiry framework (we discuss this issue more later in this article). Despite these limitations, the purpose of this study was not to make generalizations about all social presence research or definitions. Instead, our purpose was to use an exploratory approach to better understand how researchers defined social presence, which we hoped would then open a dialogue about how researchers might define social presence in the future.

\section{Results and Discussion}

In the following section, we present the results of our inquiry and briefly discuss the results.

\section{Research Question 1: How do researchers define social presence in highly cited social presence research?}

To better understand how researchers defined social presence, we looked to see if the definition(s) focused on (a) being salient, (b) being real, (c) being there, (d) projecting oneself, a sense of connection, (f) a sense of belonging, and/or (g) a sense of community. We report and discuss the results for each below.

Being salient: 18 out of 50 (36\%) researchers defined social presence in terms of being salient or salience (see Table 2). When doing so, each of these researchers cited the work of Short et al. (1976). For instance, So and Brush (2008, p. 320) stated:

Short, Williams, and Christie (1976) first introduced the concept of social presence in the field of social psychology and communication, and defined the term as the "degree of salience of the other person in the interaction and the consequent salience of the interpersonal relationships" (p. 65).

Taking a similar approach, Dunlap and Lowenthal (2009, p. 130) paraphrased Short et al. by explaining that: social presence was used to describe the degree of salience (i.e., quality or state of "being there") between two communicators using a communication medium (Short, Williams, \& Christie, 1976). 
This is an author-produced, peer-reviewed version of this article. The final, definitive version of this document can be found online at Distance Education, published by Routledge. Copyright restrictions may apply. doi: 10.1080/01587919.2017.1324727

While the Oxford Dictionary defines salience as "the quality of being particularly noticeable or important; prominence" (see https://goo.gl/VfYZlL), researchers of social presence and online learning often think of salience simply as being "real" or being "there"; this trend is evident in definitions that define social presence as being "real" or being "there."

Being Real: 19 out of 50 (38\%) researchers defined social presence in terms of being "real." The majority of the time when researchers defined social presence in terms of being "real," they cited or quoted one of the following definitions:

- Gunawardena (1995) "the degree to which a person is perceived as a "real person" in mediated communication” (p. 151);

- Gunawardena and Zittle (1997) "the degree to which a person is perceived as "real" in mediated communication" (p. 8);

- or Garrison et al. (2000) "the ability of participants in the Community of Inquiry to project their personal characteristics into the community, thereby presenting themselves to the other participants as 'real people”" (p. 89).

This is not that surprising; researchers often cite foundational literature, which in this context would be Gunawardena and Garrison et al. The appeal of Gunawardena's definition also could lie in its apparent simplicity. Rather than mention salience, Gunawardena simply reworded Short et al.'s original definition in simpler terms. For instance, Gunawardena and Zittle (1997) explained that,

Short et al., (1976) defined social presence as the 'degree of salience of the other person in the interaction and the consequent salience of the interpersonal relationships...' (p. 65). This means the degree to which a person is perceived as a "real person" in mediated communication. (p. 9)

Gunawardena, however, understood being "real” as more than simply perceiving that another is a real human being. A closer look at Gunawardena's social presence scale-which includes questions like, "I was able to form distinct individual impressions of some GlobalEd participants even though we communicated only via a text-based medium" (p. 15)—suggests that Gunawardena understood being a "real person" more in terms of getting to know another's personality and what makes someone an individual.

Garrison et al. (2000) cited Gunawardena's work. And like Gunawardena (1995), they defined social presence in terms of being real, but they specifically situated their definition of social presence within a Community of Inquiry and clarified that it is through projecting one's personal characteristics that one establishes oneself as a real person. It is important to note that unlike other fields (e.g., gaming or virtual reality), experienced online educators and online learners, like Gunawardena and Garrison et al., tend to assume that others in their class are real human beings (Kehrwald, 2008). So, when they talk about "being real," it is usually in terms with what makes people different, unique.

Being There: Only 8 out of 50 (16\%) researchers defined social presence in terms of "being there." Those who did tended to paraphrase Short et al. and describe salience as a quality of being "there" (see Lowenthal, 2009 or Table 1). Describing salience as "being there," though, is also likely due to Short et al.'s (1976) comparison of social presence to the social psychology concept of immediacy. Short et al. (1976) described immediacy as "a measure of the psychological distance which a communicator puts between himself and the object of his communication, his addressee or his communication" (p. 72). They explained, "a person can convey immediacy or non-immediacy nonverbally as well as verbally (e.g., by physical proximity, formality of dress, and facial expression)” (p. 73). While not evident in the articles and book chapters in this sample, we have found that researchers of social presence and online learning often describe social presence in terms of immediacy. In fact, both Gunawardena and Zittle (1997) and Rourke, Anderson, Garrison, and Archer (1999) created instruments to measure social presence based on the literature on immediacy.

Some researchers, though, understand "being there" differently. Take for instance the following two examples from our sample:

- Rogers and Lea (2005): "Presence...broadly defined as the sense of 'being there in a mediated environment” (p. 151). 
This is an author-produced, peer-reviewed version of this article. The final, definitive version of this document can be found online at Distance Education, published by Routledge. Copyright restrictions may apply. doi: 10.1080/01587919.2017.1324727

- Rovai (2002a): “'Social presence in cyberspace takes on more of a complexion of reciprocal awareness by others of an individual and the individual's awareness of others...to create a mutual sense of interaction that is essential to the feeling that others are there' (Cutler, 1995, p. 18)" (Social Presence Section).

Researchers like these—and others in fields like Human Computer Interaction—conceptualize social presence more in terms of "being with another" or what is sometimes called physical presence or co-presence or even telepresence (see Biocca, Harms, \& Burgoon, 2003; Kreijns et al., 2011; Kreijns, et al., 2014; Lombard \& Ditton, 1997).

Projecting Oneself: 22 out of 50 (44\%) researchers defined social presence in terms of "projecting oneself" into a community - each one quoting or citing the CoI framework. While Gunawardena was one of the first researchers to talk about how projecting one's personality can create a sense of social presence, Garrison et al. (2000) helped popularize this idea when they defined social presence as "the ability of participants in the Community of Inquiry to project their personal characteristics into the community, thereby presenting themselves to the other participants as 'real people'” (p. 89). They later shortened this definition in their next article when they defined social presence "as the ability of learners to project themselves socially and affectively into a community of inquiry” (Rourke et al., 1999, p. 50). However, the following definitions illustrate how Garrison and his colleagues continued to make subtle changes to how they defined social presence over the years:

- Vaughan and Garrison (2005): "Social presence refers to the potential of participants to project themselves socially and emotionally (i.e., their personality) within the medium of communication (Garrison et al., 2000, p. 94)” (p. 2).

- Garrison (2007): "Social presence is described as the ability to project one’s self and establish personal and purposeful relationships" (p. 63)

- Garrison, Cleveland-Innes, \& Fung (2010): "We define social presence here as 'the ability of participants to identify with the community (e.g., course of study), communicate purposefully in a trusting environment, and develop inter-personal relationships by way of projecting their individual personalities' (Garrison, 2009)” (p. 32).

Despite the subtle differences, when researchers defined social presence as "projecting oneself" into a community, they appear to be talking about projecting one's personality or identity into the course — which is another way of thinking about establishing oneself as a real person. While researchers of online learning rarely focus on social presence and identity as related or dependent constructs (for a few notable exceptions see Dennen, 2007; Rogers \& Leas, 2005), conceptualizing social presence in terms of being "real" or projecting oneself socially and emotionally inevitably involves identity work. People develop multiple identities throughout their lives (Gee, 2003); these identities change and are influenced by one's context (Nasir \& Hand, 2006). Thus, when projecting one's identity into an online course, faculty and students must think about what identity they want to share, and are comfortable with sharing, and how adept they are at projecting this identity in what is often a primarily text-based environment. While some researchers have described this ability to effectively communicate in text-based environments as a type of literacy in and of itself (see, Dunlap, Bose, Lowenthal, York, Atkinson, \& Murtagh, 2015; Whiteside, 2015), others have questioned the practice of understanding social presence-and what they see as a "perceptual phenomenon" —as an ability, as the Community of Inquiry framework has done over the years (Kreijns, et al., 2014, p. 7). In fact, Kreijns et al. are critical of those who maintain that "the competency to develop social presence is social presence" (p. 8).

Connection: 9 out of 50 (18\%) researchers defined social presence in terms of "connection" or "connectedness." These definitions tended to describe social presence as a feeling of being socially and emotionally connected to others. The following are a few different examples:

- Swan and Shih (2005) “'Social presence,' the degree to which participants in computer- mediated communication feel affectively connected one to another, has been shown to be an important factor in student satisfaction and success in online courses” (p. 115).

- Swan et al. (2008) "Social presence refers to the degree to which learners feel socially and emotionally connected with others in an online environment” (p. 1). 
This is an author-produced, peer-reviewed version of this article. The final, definitive version of this document can be found online at Distance Education, published by Routledge. Copyright restrictions may apply. doi: 10.1080/01587919.2017.1324727

These definitions focus more on people being joined together or linked in a social and emotional way than on one simply projecting his or her personality or sensing that another is "real" or even "there." A problem, though, with conceptualizing social presence in terms of connecting with others is that it becomes difficult to differentiate social presence from community (see Rovai, 2001, 2002a). Rovai (2002b), through years of research on classroom community in online courses, developed a Classroom Community Community Scale with two subscales, one focused on connectedness and one on learning; in other words, Rovai saw a sense of connectedness as being synonymous with a sense of community. Bolliger and Inan (2012) also differentiated a sense of connectedness from social presence (also see Slagter van Tryon \& Bishop, 2009, 2012, for more on social connectedness in online learning). Thus, we contend that defining social presence in terms of connectedness is problematic because it blurs the lines between social presence and a sense of community.

Belonging: 11 out of 50 (22\%) researchers defined social presence in terms of "belonging." Over the years, other researchers have also understood social presence in terms of belonging (see Caspi \& Blau, 2008). In fact, Garrison, Anderson, and Archer (2010) explained, when reflecting on the CoI framework, that prior to the development of the CoI framework, "the research on social presence was a one dimensional construct associated with an emotional sense of belonging” (p. 7). However, within this sample, when researchers defined social presence in terms of belonging, they were more often than not citing Picciano (2002), which states:

presence is “an 'illusion of nonmediation' which occurs when a person fails to perceive the existence of a medium in his/her communication environment" and that "the social component of this definition refers to a student's sense of belonging in a course or group and the ability to interact with others, although physical contact is not available". (p. 25)

Community: The last construct we looked for was community. To our surprise, in this sample, while a number of researchers defined social presence in terms of belonging or connection - which are very similar constructs to "community" - only 1 out of 50 (2\%) researchers defined social presence in terms of "community." In their highly cited article, Tu and McIsaac's (2002) defined social presence as "a measure of the feeling of community that a learner experiences in an online environment” (p. 131). It is difficult to focus too much on this single definition because Tu, like other early prolific researchers of social presence, used a number of different definitions of social presence (Kreijns et al., 2011). But even though Tu and McIsaac (2002) were the only ones in the sample to define social presence as a feeling of community, researchers regularly obscure the relationship between social presence and community in online courses. The problem with this is that years of research suggest that social presence is needed to establish a sense community in online learning environments (Brady, Holcomb, \& Smith, 2010; Hostetter \& Busch, 2006; Rovai, 2000, 2002a; Swan, 2003). The basic idea is that one cannot develop a sense of community if one does not have a sense that there are others that are "real" and "there." Thus, for most researchers, social presence is not the same thing as community. In fact, one can develop a sense of social presence but not a sense of community in the same online course (Wise, Chang, Duffy, \& Valle, 2004). Rovai (2002a) suggests that this is because a heightened sense of social presence is needed to nurture and support a sense of classroom community.

Even the popular and very influential Community of Inquiry framework is not as clear as it could be about the relationship between social presence and community. Garrison et al.'s early definitions suggest that students must project themselves into a pre-existing community of inquiry, but later definitions suggest that a CoI is the integration of all three presences (see Akyol \& Garrison, 2008). Part of the confusion, we believe, is due to how researchers sometimes use words like "community" or "learning community" when they simply mean "group of students" or even "online course." For instance, at what point does an online course become a learning community or community of inquiry and is there even a meaningful distinction between a learning community and a community of inquiry?

Garrison and his colleagues have acknowledged that the CoI framework is a model designed for a certain type of online course, which Shea and Bidjerano (2010) call collaborative online learning environments. In many ways, the CoI framework was designed to differentiate collaborative online courses - which Garrison et al. suggest is an ideal online learning experience - from previous types of distance education. Garrison (2007) has even pointed out that "social presence is of less importance [in an online course] if the learning activities are information acquisition and there are no collaborative assignments where students can benefit from the perspectives of others” (p. 63). We posit, though, that collaboration is another ill- defined word that is used in various ways in the online learning literature. Some researchers use the word collaboration when they simply mean interaction. An online course might be discussion centered, but not a course in which students truly collaborate on assignments. Further, collaborating on an assignment 
This is an author-produced, peer-reviewed version of this article. The final, definitive version of this document can be found online at Distance Education, published by Routledge. Copyright restrictions may apply. doi: 10.1080/01587919.2017.1324727

does not necessarily guarantee that a sense of community is developed or will develop. Unlike Gunawardena (1995), we do not believe social presence and a sense of community are required for collaborative learning and knowledge building; developing a sense of community in an online course is a worthy goal but we posit that students can collaborate and build knowledge without developing a sense of community (see Wilson, Ludwig-Hardman, Thornam, \& Dunlap, 2004, for more on bounded learning communities and how community in online courses differ from communities of practice; and see Feenberg, 1989, for an early discussion on focusing too much on community with learning online).

A few trends stand out when looking at how researchers define social presence in highly cited research. First, as initially suspected, researchers define social presence very differently. Second, 7 out of 50 (14\%) researchers did not clearly define social presence. Third, the influence of Short et al., Gunawardena, and Garrison et al.'s work is evident in researchers' definitions of social presence. And fourth, about $20 \%$ of the time researchers conceptualize social presence as something more than simply being perceived as a real person, invoking ideas of connection, belonging, and community.

Table 2

Constructs Appearing in Highly Cited Definitions of Social Presence

\begin{tabular}{lc}
\hline Construct & Frequency \\
\hline Salience & $18(36 \%)$ \\
Being real & $19(38 \%)$ \\
Being there & $8(16 \%)$ \\
Projecting oneself & $22(44 \%)$ \\
Connection & $9(18 \%)$ \\
Belonging & $11(22 \%)$ \\
Community & $1(2 \%)$ \\
\hline
\end{tabular}

\section{Research Question 2: How prevalent is the Community of Inquiry framework in highly cited social presence research?}

Even though the theory of social presence dates back to the 1970s, once we began our initial analysis of definitions, we became interested in finding out how prevalent the CoI framework was in highly cited social presence research. We were interested in this because we kept seeing articles or book chapters written by Garrison and his colleagues, or their work being cited, and were curious whether it is reasonable to suspect that the CoI framework -in part because of its popularity—might be shaping the discourse around social presence and online learning.

We found that Garrison, Anderson, and Archer authored or co-authored 13 out of 50 (26\%) of the highly cited articles or book chapters that made up the sample of this study. We then analyzed the reference lists of all 50 articles and book chapters and found that the work of Garrison, Anderson, and Archer were cited in 41 out of 50 (82\%) articles and book chapters. In comparison, Gunawardena was cited in 34 out of 50 (68\%) and Short et al. were cited 30 out of 50 (60\%) (see Table 3). We specifically noticed that Garrison and his colleagues stopped citing Short and Gunawardena after their first few articles (in this sample), opting instead to ground their work in their previous research. These results suggest that even in this small sample, the CoI framework is highly influential and possibly heavily shaping the direction of social presence research in online learning The problem with this is that other notable scholarship on social presence and online learning gets less attention, if not ignored all together, or researchers feel pressure to ground their work in the CoI framework to appease peer reviewers. 
This is an author-produced, peer-reviewed version of this article. The final, definitive version of this document can be found online at Distance Education, published by Routledge. Copyright restrictions may apply. doi: 10.1080/01587919.2017.1324727

Table 3

Frequency that Foundational Social Presence Researchers are Cited

\section{Foundational Researchers}

Cited Short

Cited Gunawardena

Cited Community of Inquiry

\section{Frequency}

$30(60 \%)$

$34(68 \%)$

$41(82 \%)$

\section{Research Question 3: How have highly cited researchers changed their definition over time?}

Last but not least, we were interested in how definitions of social presence might be changing over time. We approached answering this question in two ways. We first looked at the articles in the sample published since 2010 to see if we saw any common trends across how the researchers defined social presence. Nothing stood out. ${ }^{1}$ Thus, recognizing how prevalent the CoI framework is in this sample as well as the number of articles authored or coauthored by Garrison, we decided to look at how Garrison has redefined social presence over the years. Take a look at the following five definitions from our sample.

- "The second element of the model, social presence, is defined as the ability of participants in the Community of Inquiry to project their personal characteristics into the community, thereby presenting themselves to the other participants as 'real people’” (Garrison et al., 2000, p. 89)

- "Social presence is defined as the ability of learners to project themselves socially and affectively into a community of inquiry” (Rourke et al., 1999, p. 50)

- "Social presence is described as the ability to project one's self and establish personal and purposeful relationships” (Garrison, 2007, p. 63)

- "Subsequently, Garrison (2009b) has tried to provide a stronger link between social presence and the purposeful, academic nature of the inquiry process. In this regard, there is evidence to suggest that the first priority for most students in a formal educational context is shared social identity (i.e., the purpose of the course), and not personal identity (i.e., interpersonal relationships). As a result, it is argued that the three dimensions of social presence may be defined in terms of the participants identifying with the community, communicating purposefully in a trusting environment, and developing interpersonal relationships (Garrison, 2009b).” (Garrison, Anderson, \& Archers, 2010, p. 7)

- "We define social presence here as 'the ability of participants to identify with the community (e.g., course of study), communicate purposefully in a trusting environment, and develop interpersonal relationships by way of projecting their individual personalities' (Garrison, 2009)” (Garrison, Cleveland-Innes, \& Fung, 2010, p. 32)

Garrison's definition has changed over time. This is not surprising; researchers regularly seek to improve their work, and definitions and even theories rarely remain unchanged over time. Even those who heavily rely on the work of Short et al. tend to understand social presence in a less technologically deterministic way than Short et al. originally did (Kehrwald, 2008). Garrison, Anderson, and Archer (2010), though, point out in a retrospective that they saw that "an important contribution of ... [their] work was describing social presence from a multi- dimensional perspective that had overlap with other presences” (p. 7). They continued to explain that Garrison's 2009 definition (cited in the previous paragraph) was an intentional effort "to provide a stronger link between social presence and the purposeful, academic nature of the inquiry process” (p. 7).

\footnotetext{
${ }^{1}$ Future research could analyze recent research (e.g., work published during the last five years) to see how definitions of social presence might be changing over time.
} 
This is an author-produced, peer-reviewed version of this article. The final, definitive version of this document can be found online at Distance Education, published by Routledge. Copyright restrictions may apply. doi: 10.1080/01587919.2017.1324727

While some researchers are trying to simplify how to define and conceptualize social presence (see Kreijns, et al. 2004, 2011; Kreijns, et al., 2014), Garrison et al. believe that a multi- faceted definition is more useful for the research and practice of online learning. The question remains whether this recent definition of Garrison's tries to accomplish too much. For instance, from a practical perspective, what happens if a student is taking a required course in which he or she does not identify with the course of study? Or what happens when a student is able to project his or her individual personality but does not form interpersonal relationships (i.e., strong relationships)? Is he or she unable to establish social presence? Does a community of inquiry not form? One thing is clear: Garrison is a highly influential, respected, and cited researcher. Therefore, researchers of social presence should pay attention to when Garrison redefines a construct, like social presence, that is central to the research and practice of online learning. However, researchers should also recognize that the CoI framework is an idealized model for a certain type of online course, it is not set in stone, and it is only one perspective of how to understand the role of social presence in online courses.

\section{Conclusion}

Researchers of online learning regularly use the construct of social presence to understand how people socially interact in online learning environments. Given the overall popularity of social presence-and yet various ways researchers define it - we investigated just how differently researchers, in highly cited articles, defined social presence. We found, in our sample of highly cited articles, that researchers tended to define social presence either in terms of the behaviors one uses (e.g., immediacy behaviors) and/or the degree to which one perceives another person(s) as being a "real" person (and to a lesser degree, "there") when using a communication medium. However, about $20 \%$ of the time researchers defined social presence as something more than simply being perceived as a real person, invoking ideas of connection, belonging, and community - which Kreijns et al. (2014) suggests confuses social presence with social space. While we understand why researchers have done this--and the first author has even done this in his own work, we believe that this confuses what social presence is with what it should do in an online course.

Our results also revealed that the CoI framework, and specifically the work of Garrison, continues to influence social presence research. However, as useful as the CoI framework and Garrison's work are for the research and practice of online learning, we contend that they can limit or complicate researchers understanding of social presence. The CoI framework conceptualizes social presence only in terms of its relationship to teaching presence and cognitive presence in collaborative online learning environments. Students are social creatures and, given time and interest in interacting with others, will find ways to establish their social presence on their own without the teacher's help (see Annand, 2011; Dunlap \& Lowenthal, 2014). Therefore, we contend that social presence is not inherently dependent on teaching presence. Further, social presence might not be essential for a meaningful educational experience. The CoI framework is an idealized model for a certain type of online course (i.e., collaborative online learning environments) —and possibly a certain type of learner (Annand, 2011; Arbaugh, Bangert, \& Cleveland-Innes, 2010). This suggests that the CoI framework might be of limited value for online courses that rely little, if at all, on collaborative assignments or for students who do not value heavy social interaction.

Anderson, one of the original developers of the CoI, later developed the Interaction Equivalency Theorem, which raises questions about the CoI framework's central claim that social presence is essential for a meaning educational experience. Anderson (2003) explains

Deep and meaningful formal learning is supported as long as one of the three forms of interaction (student-teacher; student-student; student-content) is at a high level. The other two may be offered at minimal levels, or even eliminated, without degrading the educational experience. ("Equivalency of Interaction” section, para. 2)

While Anderson is focused on interaction and not necessarily social presence, research on social presence suggests that one cannot have social presence without student-student and student- teacher interaction. Anderson went on to explain:

High levels of more than one of these three modes will likely provide a more satisfying educational experience, through these experiences may not be as cost or time effective as less interactive learning sequences. (“Equivalency of Interaction” section, para. 2)

This suggests that as useful as social presence might be for collaborative online learning experiences, it is not necessarily required or essential for students to learn online. 
This is an author-produced, peer-reviewed version of this article. The final, definitive version of this document can be found online at Distance Education, published by Routledge. Copyright restrictions may apply. doi: 10.1080/01587919.2017.1324727

Moving forward, we believe that the research and practice of online learning would be improved if researchers first clearly explained how social presence is defined in the literature and then clearly defined how they understand social presence. Unlike Garrison, we prefer simple definitions and believe that it is important not to confuse social presence with collaboration or community. Social presence, collaboration, and community are three important, yet different, constructs in the online learning literature. While our results are not meant to be generalizable, we hope that our findings and discussion will help inform the research and practice of online learning and ultimately that researchers will carefully consider how they define social presence in the future.

\section{$\underline{\text { Notes on Contributors }}$}

Patrick R. Lowenthal, Ph.D., is an Associate Professor at Boise State University, where he teaches master's and doctoral students in fully online graduate programs. He researches how people communicate using emerging technologies - with a specific focus on issues of presence, identity, and community online.

Dr. Chareen Snelson is an Associate Professor and Associate Department Head in a fully online Educational Technology program at Boise State University. She has worked in online education for more than fifteen years having designed and taught a wide variety of graduate-level educational technology courses including media design and leadership. Her scholarly activity and research emphasis focuses on topics in educational video production, educational applications of YouTube, media literacy, qualitative social media research methods, and massively multiplayer online games.

\section{References}

Akyol, Z., \& Garrison, D. R. (2008). The development of a community of inquiry over time in an online course: Understanding the progression and integration of social, cognitive and teaching presence. Journal of Asynchronous Learning Networks, 12, 3-22. DOI: http://dx.doi.org/10.24059/olj.v12i3.72

Anderson, T. (2003). Getting the mix right again: An updated and theoretical rationale for interaction. International Review of Research in Open and Distributed Learning, 4(2). Retrieved from http://www.irrodl.org/index.php/irrodl/article/view/149/230

Annand, D. (2011). Social presence within the community of inquiry framework. International Review of Research in Open and Distributed Learning, 12(5), 40-56. Retrieved from http://www.irrodl.org/index.php/irrodl/article/view/924/1855

Arbaugh, J. B., Bangert, A., \& Cleveland-Innes, M. (2010). Subject matter effects and the community of inquiry (CoI) framework: An exploratory study. The Internet and Higher Education, 13(1), 37-44.

Biocca, F., Harms, C., \& Burgoon, J. K. (2003). Toward a more robust theory and measure of social presence: Review and suggested criteria. Presence: Teleoperators and virtual environments, 12(5), 456-480. DOI: http://dx.doi.org/10.1162/105474603322761270

Bolliger, D. U., \& Inan, F. A. (2012). Development and validation of the online student connectedness survey (OSCS). International Review of Research in Open and Distributed Learning, 13(3), 41-65. Retrieved from http://www.irrodl.org/index.php/irrodl/article/view/1171/2206

Brady, K. P., Holcomb, L. B., \& Smith, B. V. (2010). The use of alternative social networking sites in higher educational settings: A case study of the e-learning benefits of Ning in education. Journal of Interactive Online Learning, 9(2), 151-170. Retrieved from http://www.ncolr.org/jiol/issues/pdf/9.2.4.pdf

Caspi, A., \& Blau, I. (2008). Social presence in online discussion groups: Testing three conceptions and their relations to perceived learning. Social Psychology of Education, 11(3), 323-346. DOI: http://dx.doi.org/10.1007/s11218-008-9054-2

Dennen, V. (2007). Presence and positioning as components of online instructor persona. Journal of Research on Technology in Education, 40(1), 95-108. DOI: http://dx.doi.org/10.1080/15391523.2007.10782499

Dunlap, J., Bose, D., Lowenthal, P. R., York, C. S., Atkinson, M., \& Murtagh, J. (2016). What sunshine is to flowers: A literature review on the use of emoticons to support online learning. In S. Y. Tettegah \& M. Gartmeier (Eds.), Emotions, Design, Learning and Technology (pp. 163-182). San Diego, CA: Elsevier.

Dunlap, J. C., \& Lowenthal, P. R. (2009). Tweeting the night away: Using Twitter to enhance social presence. Journal of Information Systems Education, 20, 129-136.

Dunlap, J. C., \& Lowenthal, P.R. (2014). The power of presence: Our quest for the right mix of social presence in online courses. In A. A. Piña \& A. P. Mizell (Eds.), Real life distance education: Case studies in practice (pp. 41-66). Greenwich, CT: Information Age Publishing. 
This is an author-produced, peer-reviewed version of this article. The final, definitive version of this document can be found online at Distance Education, published by Routledge. Copyright restrictions may apply. doi: 10.1080/01587919.2017.1324727

Feenberg, A. (1989). The written world: On the theory and practice of computer conferencing. In R. Mason \& A. Kaye (Eds.), Mindweave: Communication, computers, and distance education (pp. 22-39). Oxford: Pergamon Press.

Garrison, D. R. (2007). Online Community of Inquiry review: Social, cognitive, and teaching presence issues. Journal of Asynchronous Learning Networks, 11, 61-72. Retrieved from https://onlinelearningconsortium.org/read/online-learning-journal/

Garrison, D. R. (2009). Communities of inquiry in online learning. In P. L. Rogers (Ed.), Encyclopedia of distance learning (pp. 352-355; 2nd ed.). Hershey, PA: IGI Global.

Garrison, D. R., Anderson, T., \& Archer, W. (2000). Critical inquiry in a text-based environment: Computer conferencing in higher education. Internet and Higher Education, 2(2-3), 87-105. DOI: http://dx.doi.org/10.1016/S1096-7516(00)00016-6

Garrison, D. R., Anderson, T., \& Archer, W. (2010). The first decade of the community of inquiry framework: A retrospective. Internet and Higher Education, 13(1), 5-9. DOI: http://dx.doi.org/10.1016/j.iheduc.2009.10.003

Garrison, D. R., Cleveland-Innes, M., \& Fung, T. S. (2010). Exploring causal relationships among teaching, cognitive and social presence: Student perceptions of the community of inquiry framework. Internet and Higher Education, 1, 31-36. DOI: doi:10.1016/j.iheduc.2009.10.002

Gee, J. P. (2003). What video games have to teach us about learning and literacy. New York, NY: Palgrave Macmillan.

Gunawardena, C. N. (1995). Social presence theory and implications for interaction and collaborative learning in computer conferences. International Journal of Educational Telecommunications, 1(2/3), 147-166. Retrieved from http://www.learntechlib.org/d/15156

Gunawardena, C. N., \& Zittle, F. J. (1997). Social presence as a predictor of satisfaction within a computer-mediated conferencing environment. American Journal of Distance Education, 11(3), 8-26. DOI: http://dx.doi.org/10.1080/08923649709526970

Hostetter, C., \& Busch, M. (2006). Measuring up online: The relationship between social presence and student learning satisfaction. Journal of Scholarship of Teaching and Learning, 6(2), 1-12. Retrieved from http://josotl.indiana.edu/article/view/1670/1668

Kawachi, P. (2013). Online social presence and its correlation with learning. International Journal of Social Media and Interactive Learning Environments, 1(1), 19-31. DOI: http://dx.doi.org/10.1504/IJSMILE.2013.051653

Kehrwald, B. (2008). Understanding social presence in text-based online learning environments. Distance Education, 29(1), 89-106.

Kreijns, K., Kirschner, P. A., Jochems, W., \& Van Buuren, H. (2004). Determining sociability, social space, and social presence in (a)synchronous collaborative groups. Cyberpsychology \& Behavior, 7, 155-172. doi:10.1089/109493104323024429 Kreijns, K., Kirschner, P. A., Jochems, W., \& Van Buuren, H. (2011). Measuring perceived social presence in distributed learning groups. Education and Information Technologies, 16(4), 365-381.

Lim, J., \& Richardson, J. C. (2016). Exploring the effects of students' social networking experience on social presence and perceptions of using SNSs for educational purposes. Internet and Higher Education, 29, 3139. DOI: http://dx.doi.org/10.1016/j.iheduc.2015.12.001

Lombard, M., \& Ditton, T. (1997). At the heart of it all: The concept of presence. Journal of Computer Mediated Communication, 3(2). Retrieved from http://onlinelibrary.wiley.com/doi/10.1111/j.10836101.1997.tb00072.x/full

Lowenthal, P. R. (2009). The evolution and influence of social presence theory on online learning. In T. T. Kidd (Ed.), Online education and adult learning: New frontiers for teaching practices (pp. 124-139). Hershey, PA: IGI Global.

Lowenthal, P. R. (2012). Social presence: What is it? How do we measure it? (Doctoral dissertation, University of Colorado Denver). Retrieved from http://search.proquest.com/docview/1014403528

Lowenthal, P. R., \& Dunlap, J. C. (2014). Problems measuring social presence in a Community of Inquiry. ELearning and Digital Media, 11(1), 19-30. DOI: 10.2304/elea.2014.11.1.19

Nasir, N. S., \& Hand, V. M. (2006). Exploring sociocultural perspectives on race, culture, and learning. Review of Educational Research, 76(4), 449-475. DOI: http://dx.doi.org/10.3102/00346543076004449 
This is an author-produced, peer-reviewed version of this article. The final, definitive version of this document can be found online at Distance Education, published by Routledge. Copyright restrictions may apply. doi: 10.1080/01587919.2017.1324727

Picciano, A. G. (2002). Beyond student perceptions: Issues of interaction, presence, and performance in an online course. Journal of Asynchronous Learning Networks, 6(1), 21-40. Retrieved from https://onlinelearningconsortium.org/read/online-learning-journal/ Rogers, P., \& Lea, M. (2005). Social presence in distributed group environments: The role of social identity. Behaviour \& Information Technology, 24, 151-158. doi:10.1080/01449290410001723472

Rourke, L., Anderson, T., Garrison, D. R., \& Archer, W. (1999). Assessing social presence in asynchronous textbased computer conferencing. Journal of Distance Education, 14(2). Retrieved from http://cade.athabascau.ca/vol14.2/rourke_et_al.html

Rourke, L., \& Kanuka, H. (2009). Learning in communities of inquiry: A review of the literature. International Journal of E-Learning \& Distance Education, 23(1), 19-48. Retrieved from http://files.eric.ed.gov/fulltext/EJ836030.pdf

Rovai, A. P. (2000). Building and sustaining community in asynchronous learning networks. Internet and Higher Education, 3(4), 285-297. DOI: http://dx.doi.org/10.1016/S1096- 7516(01)00037-9

Rovai, A. P. (2001). Building classroom community at a distance: A case study. Educational Technology Research and Development, 49(4), 33-48. DOI: http://dx.doi.org/10.1007/BF02504946

Rovai, A. P. (2002a). Building sense of community at a distance. The International Review of Research in Open and Distributed Learning, 3(1). Retrieved from http://www.irrodl.org/index.php/irrodl/article/view/79/152

Rovai, A. P. (2002b). Development of an instrument to measure classroom community. Internet and Higher Education, 5(3), 197-211. DOI: http://dx.doi.org/10.1533/9781780631622

Shea, P., \& Bidjerano, T. (2010). Learning presence: Towards a theory of self-efficacy, self- regulation, and the development of a communities of inquiry in online and blended learning environments. Computers \& Education, 55(4), 1721-1731. DOI: http://dx.doi.org/10.1016/j.compedu.2010.07.017

Short, J., Williams, E., \& Christie, B. (1976). The social psychology of telecommunications. London: John Wiley \& Sons.

Slagter van Tryon, P. J., \& Bishop, M. J. (2009). Theoretical foundations for enhancing social connectedness in online learning environments. Distance Education, 30(3), 291-315.

Slagter van Tryon, P. J., \& Bishop, M. J. (2012). Evaluating social connectedness online: the design and development of the Social Perceptions in Learning Contexts Instrument. Distance Education, 33(3), 347364.

So, H.-Y., \& Brush, T. (2008). Students perceptions of collaborative learning, social presence, and satisfaction in blended learning environment: Relationships and critical factors. Computers \& Education, 51(1), 318-336. DOI: http://dx.doi.org/10.1016/j.compedu.2007.05.009

Sung, E., \& Mayer, R. E. (2012). Five facets of social presence in online distance education. Computers in Human Behavior, 28(5), 1738-1747. DOI: http://dx.doi.org/10.1016/j.chb.2012.04.014

Swan, K. (2003). Developing social presence in online course discussions. In S. Naidu (Ed.), Learning \& Teaching with Technology: Principles and Practices (pp. 136-153). Sterling, VA: Kogan Page.

Swan, K., Shea, P., Richardson, J., Ice, P., Garrison, D. R., Cleveland-Innes, M., \& Arbaugh, J.

B. (2008). Validating a measurement tool of presence in online communities of inquiry. E-mentor, 2(24), 1-12. Retrieved from http://online.purdue.edu/sites/purdue/files/Validating-a-Measurement-Tool-of-Presence- inOnline-Communities-of-Inquiry.pdf

Swan, K., \& Shih, L. F. (2005). On the nature and development of social presence in online discussions. Journal of Asynchronous Learning Networks, 9, 115-136. Retrieved from https://onlinelearningconsortium.org/read/online-learning-journal/

Tu, C.-H. (2002). The impacts of text-based CMC on online social presence. Journal of Interactive Online Learning, 1(2), 1-24. doi:10.2224/sbp.2007.35.10.1399

Tu, C.-H., \& McIsaac, M. (2002). The relationship of social presence and interaction in online classes. American Journal of Distance Education, 16(3), 131-150. DOI: http://dx.doi.org/10.1207/S15389286AJDE1603_2

Vaughan, N., \& Garrison, D. R. (2005). Creating cognitive presence in a blended faculty development community. Internet and Higher Education, 8(1), 1-12. DOI: http://dx.doi.org/10.1016/j.iheduc.2004.11.001

Walther, J. B. (1992). Interpersonal effects in computer-mediated interaction: A relational perspective. Communication Research, 19, 52-90. DOI: http://dx.doi.org/10.1177/009365092019001003

Walther, J. B. (1996). Computer-mediated communication: Impersonal, interpersonal, and hyperpersonal interaction. Communication Research, 23(1), 3-43. DOI: http://dx.doi.org/10.1177/009365096023001001

Walther, J. B., Anderson, J. F., \& Park, D. W. (1994). Interpersonal effects in computer- mediated interaction: A meta-analysis of social and antisocial communication. Communication Research, 21(4), 460-487. DOI: http://dx.doi.org/10.1177/009365094021004002 
This is an author-produced, peer-reviewed version of this article. The final, definitive version of this document can be found online at Distance Education, published by Routledge. Copyright restrictions may apply. doi: 10.1080/01587919.2017.1324727

Walther, J. B., \& Parks, M. R. (2002). Cues filtered out, cues filtered in. In M. L. Knapp \& J. A. Daly (Eds), Handbook of interpersonal communication (pp. 529-563; 3rd ed.). Thousand Oaks, CA: Sage.

Whiteside, A. L. (2015). Introducing the Social Presence Model to explore online and blended learning experiences. Online Learning, 19(2). DOI: http://dx.doi.org/10.24059/olj.v19i2.453

Whiteside, A. L., Dikkers, A. G., \& Swan, K. (2017). Social presence in online learning: Multiple perspectives on practice and research. Sterling, VA: Stylus.

Wilson, B. G., Ludwig-Hardman, S., Thornam, C. L., \& Dunlap, J. C. (2004). Bounded community: Designing and facilitating learning communities in formal courses. The International Review of Research in Open and Distributed Learning, 5(3). Retrieved from http://www.irrodl.org/index.php/irrodl/article/view/204/286

Wise, A., Chang, J., Duffy, T., \& Valle, R. Del. (2004). The effects of teacher social presence on student satisfaction, engagement, and learning. Journal of Educational Computing Research, 31, 247-271. doi:10.2190/V0LB1M37-RNR8-Y2U1

Xin, C. (2012). A critique of the community of inquiry framework. International Journal of E- Learning \& Distance Education, 26(1). Retrieved from http://www.ijede.ca/index.php/jde/article/view/755/1333 


\section{Appendix}

\begin{tabular}{|c|c|c|}
\hline Rank & Cited & Reference \\
\hline 1 & 3706 & $\begin{array}{l}\text { Garrison, D. R., Anderson, T., \& Archer, W. (2000). Critical inquiry in a text-based environment: Computer conferencing in higher education. Internet and higher } \\
\text { education, 2(2), 87-105. DOI: http://dx.doi.org/10.1016/S1096-7516(00)00016-6 }\end{array}$ \\
\hline 2 & 1834 & $\begin{array}{l}\text { Rourke, L., Anderson, T., Garrison, D. R., \& Archer, W. (1999). Assessing social presence in asynchronous text-based computer conferencing. Journal of Distance } \\
\text { Education, 14, 50-71. Retrieved from http://cade.athabascau.ca/vol14.2/rourke_et_al.html }\end{array}$ \\
\hline 3 & 1648 & $\begin{array}{l}\text { Gunawardena, C. N., \& Zittle, F. J. (1997). Social presence as a predictor of satisfaction within a computer-mediated conferencing environment. American Journal of } \\
\text { Distance Education, 11, 8-26. DOI: http://dx.doi.org/10.1080/08923649709526970 }\end{array}$ \\
\hline 4 & 1491 & $\begin{array}{l}\text { Richardson, J. C., \& Swan, K. (2003). Examining social presence in online courses in relation to students' perceived learning and satisfaction. Journal of } \\
\text { Asynchronous Learning Network, 7,68-88. Retrieved from http://onlinelearningconsortium.org/sites/default/files/v7n1_richardson_1.pdf }\end{array}$ \\
\hline 5 & 1290 & $\begin{array}{l}\text { Picciano, A. G. (2002). Beyond student perceptions: Issues of interaction, presence, and performance in an online course. Journal of Asynchronous Learning } \\
\text { Networks, } 6(1), \quad 21-40 \text {. Retrieved from https://onlinelearningconsortium.org/read/online-learning-journal/ }\end{array}$ \\
\hline 6 & 1201 & $\begin{array}{l}\text { Kreijns, K., Kirschner, P. A., \& Jochems, W. (2003). Identifying the pitfalls for social interaction in computer-supported collaborative learning environments: A review } \\
\text { of the research. Computers in Human Behavior, 19(3), 335-353. DOI: http://dx.doi.org/10.1016/S0747-5632(02)00057-2 }\end{array}$ \\
\hline 7 & 1171 & $\begin{array}{l}\text { Rovai, A. P. (2002). Building sense of community at a distance. International Review of Research in Open and Distributed Learning, 3(1). Retrieved from } \\
\text { http://www.irrodl.org/index.php/irrodl/article/view/79/152 }\end{array}$ \\
\hline 8 & 1079 & $\begin{array}{l}\text { Gunawardena, C. N. (1995). Social presence theory and implications of interaction and collaborative learning in computer conferences. International Journal of } \\
\text { Educational Telecommunications, 1, 147-166. Retrieved from http://www.learntechlib.org/d/15156 }\end{array}$ \\
\hline 9 & 957 & $\begin{array}{l}\text { Tu, C.-H., \& Mclsaac, M. (2002). The relationship of social presence and interaction in online classes. American Journal of Distance Education, 16, 131-150. DOI: } \\
\text { http://dx.doi.org/10.1207/S15389286_AJDE1603_2 }\end{array}$ \\
\hline 10 & 902 & $\begin{array}{l}\text { Garrison, D. R., \& Cleveland-Innes, M. (2005). Facilitating cognitive presence in online learning: Interaction is not enough. American Journal of Distance Education, } \\
\text { 19(3), 133-148. DOI: http://dx.doi.org/10.1207/s15389286ajde1903_2 }\end{array}$ \\
\hline 11 & 646 & $\begin{array}{l}\text { So, H.-J., \& Brush, T. A. (2008). Student perceptions of collaborative learning, social presence and satisfaction in a blended learning environment: Relationships and } \\
\text { critical factors. Computers \& Education, 51(1), 318-336. DOI: http://dx.doi.org/10.1016/j.compedu.2007.05.009 }\end{array}$ \\
\hline 12 & 590 & $\begin{array}{l}\text { Anderson, T., \& Dron, J. (2011). Three generations of distance education pedagogy. International Review of Research in Open and Distributed Learning, 12(3), 80- } \\
\text { 97. Retrieved from http://www.irrodl.org/index.php/irrodl/article/view/890/1826 }\end{array}$ \\
\hline 13 & 555 & $\begin{array}{l}\text { Swan, K., \& Shih, L. F. (2005). On the nature and development of social presence in online discussions. Journal of Asynchronous Learning Networks, } 9,115-136 . \\
\text { Retrieved from https://onlinelearningconsortium.org/read/online-learning-journal/ }\end{array}$ \\
\hline 14 & 514 & $\begin{array}{l}\text { Dunlap, J. C., \& Lowenthal, P. R. (2009). Tweeting the night away: Using Twitter to enhance social presence. Journal of Information Systems Education, 20, 129- } \\
\text { 136. }\end{array}$ \\
\hline 15 & 496 & Aragon, S. R. (2003). Creating social presence in online environments. New Directions for Adult and Continuing Education, 200, 57-68. \\
\hline 16 & 477 & $\begin{array}{l}\text { Garrison, D. R. (2007). Online Community of Inquiry review: Social, cognitive, and teaching presence issues. Journal of Asynchronous Learning Networks, 11, 61- } \\
\text { 72. Retrieved from https://onlinelearningconsortium.org/read/online-learning-journal/ }\end{array}$ \\
\hline 17 & 402 & $\begin{array}{l}\text { Tu, C.-H. (2002). The measurement of social presence in an online learning environment. International Journal on E-Learning, 1, 34-45. Retrieved from } \\
\text { https://www.learntechlib.org/p/10820 }\end{array}$ \\
\hline 18 & 367 & $\begin{array}{l}\text { Garrison, D. R., Anderson, T., \& Archer, W. (2010). The first decade of the community of inquiry framework: A retrospective. Internet and Higher Education, 13(1), 5- } \\
\text { 9. DOI: http://dx.doi.org/10.1016/j.iheduc.2009.10.003 }\end{array}$ \\
\hline 19 & 342 & $\begin{array}{l}\text { Arbaugh, J. B., Cleveland-Innes, M., Diaz, S. R., Garrison, D. R., Ice, P., Richardson, J. C., \& Swan, K. P. (2008). Developing a community of inquiry instrument: } \\
\text { Testing a measure of the community of inquiry framework using a multi-institutional sample. Internet and Higher Education, 11(3), 133-136. DOI: } \\
\text { http://dx.doi.org/10.1016/j.ineduc.2008.06.003 }\end{array}$ \\
\hline 20 & 341 & $\begin{array}{l}\text { Garrison, D. R., Cleveland-Innes, M., \& Fung, T. S. (2010). Exploring causal relationships among teaching, cognitive and social presence: Student perceptions of the } \\
\text { community of inquiry framework. Internet and Higher Education, 1, 31-36. doi:10.1016/j.iheduc.2009.10.002 }\end{array}$ \\
\hline 21 & 297 & $\begin{array}{l}\text { Tu, C.-H. (2000). On-line learning migration: From social learning theory to social presence theory in a CMC environment. Journal of Network and Computer } \\
\text { Applications, 23, 27-37. DOI: http://dx.doi.org/10.1006/jnca.1999.0099 }\end{array}$ \\
\hline 22 & 295 & $\begin{array}{l}\text { Shea, P., \& Bidjerano, T. (2009). Community of inquiry as a theoretical framework to foster "epistemic engagement" and "cognitive presence" in online education. } \\
\text { Computers \& Education, 52(3), 543-553. http://doi.org/10.1016/j.compedu.2008.10.007 }\end{array}$ \\
\hline
\end{tabular}




\begin{tabular}{|c|c|c|}
\hline 23 & 287 & $\begin{array}{l}\text { Akyol, Z., \& Garrison, D. R. (2008). The development of a community of inquiry over time in an online course: Understanding the progression and integration of } \\
\text { social, cognitive and teaching presence. Journal of Asynchronous Learning Networks, 12, 3-22. DOI: http://dx.doi.org/10.24059/olj.v12i3.72 }\end{array}$ \\
\hline 24 & 281 & $\begin{array}{l}\text { Kehrwald, B. (2008). Understanding social presence in text-based online learning environments. Distance Education, 29(1), 89-106. DOI: } \\
\text { http://dx.doi.org/10.1080/01587910802004860 }\end{array}$ \\
\hline 25 & 276 & $\begin{array}{l}\text { Shea, P., \& Bidjerano, T. (2010). Learning presence: Towards a theory of self-efficacy, self-regulation, and the development of a communities of inquiry in online and } \\
\text { blended learning environments. Computers \& Education, 55(4), 1721-1731. DOI: http://dx.doi.org/10.1016/j.compedu.2010.07.017 }\end{array}$ \\
\hline 26 & 254 & $\begin{array}{l}\text { Hayashi, A., Chen, C., \& Ryan, T. (2004). The role of social presence and moderating role of computer self efficacy in predicting the continuance usage of e-learning } \\
\text { systems. Journal of Information Systems Education, 15, 139-155. Retrieved from http://jise.org/Volume15/15-1/Pdf/139-Abs.pdf }\end{array}$ \\
\hline 27 & 247 & $\begin{array}{l}\text { Anderson, T. (2005). Distance learning-social software's killer ap?. Proceedings of the Open \& Distance Learning Association (ODLAA) of Australia. Adelaide: } \\
\text { ODLAA. Retrieved from http://auspace.athabascau.ca:8080/bitstream/2149/2328/1/distance_learning.pdf }\end{array}$ \\
\hline 28 & 246 & $\begin{array}{l}\text { Brady, K. P., Holcomb, L. B., \& Smith, B. V. (2010). The use of alternative social networking sites in higher educational settings: A case study of the e-learning } \\
\text { benefits of Ning in education. Journal of Interactive Online Learning, 9(2), 151-170. Retrieved from http://www.ncolr.org/jiol/issues/pdf/9.2.4.pdf }\end{array}$ \\
\hline 29 & 246 & $\begin{array}{l}\text { Tu, C. (2001). How Chinese perceive social presence: An examination of interaction in online learning environment. Educational Media International, 38(1), 45-60. } \\
\text { DOI: http://dx.doi.org/10.1080/09523980010021235 }\end{array}$ \\
\hline 30 & 245 & $\begin{array}{l}\text { Vaughan, N., \& Garrison, D. R. (2005). Creating cognitive presence in a blended faculty development community. Internet and higher education, 8(1), 1-12. DOI: } \\
\text { http://dx.doi.org/10.1016/j.iheduc.2004.11.001 }\end{array}$ \\
\hline 31 & 219 & $\begin{array}{l}\text { Shin, N. (2002). Beyond interaction: The relational construct of 'transactional presence'. Open Learning, 17(2), 121-137. DOI: } \\
\text { http://dx.doi.org/10.1080/02680510220146887 }\end{array}$ \\
\hline 32 & 210 & $\begin{array}{l}\text { Kreijns, K., Kirschner, P. A., Jochems, W., \& Van Buuren, H. (2004). Determining sociability, social space, and social presence in (a)synchronous collaborative } \\
\text { groups. Cyberpsychology \& Behavior, 7, 155-172. doi:10.1089/109493104323024429 }\end{array}$ \\
\hline 33 & 205 & $\begin{array}{l}\text { Russo, T., \& Benson, S. (2005). Learning with invisible others: Perceptions of online presence and their relationship to cognitive and affective learning. Educational } \\
\text { Technology \& Society, 8(1), 54-62. Retrieved from http://www.ifets.info/journals/8_1/8.pdf }\end{array}$ \\
\hline 34 & 177 & $\begin{array}{l}\text { Rourke, L., \& Anderson, T. (2002). Exploring social communication in computer conferencing. Journal of Interactive Learning Research, 13(3), 259-276. Retrieved } \\
\text { from https://www.learntechlib.org/p/15133 }\end{array}$ \\
\hline 35 & 174 & $\begin{array}{l}\text { Wise, A., Chang, J., Duffy, T., \& Valle, R. Del. (2004). The effects of teacher social presence on student satisfaction, engagement, and learning. Journal of } \\
\text { Educational Computing Research, 31,247-271. doi:10.2190/VOLB-1M37-RNR8-Y2U1 }\end{array}$ \\
\hline 36 & 172 & $\begin{array}{l}\text { Swan, K., Shea, P., Richardson, J., Ice, P., Garrison, D. R., Cleveland-Innes, M., \& Arbaugh, J. B. (2008). Validating a measurement tool of presence in online } \\
\text { communities of inquiry. E-mentor, 2(24), 1-12. Retrieved from http://online.purdue.edu/sites/purdue/files/Validating-a-Measurement-Tool-of-Presence-in-Online- } \\
\text { Communities-of-Inquiry.pdf }\end{array}$ \\
\hline 37 & 170 & $\begin{array}{l}\text { Stacey, E. (2002). Social presence online: networking learners at a distance. In D. Watson \& J. Andersen (Eds.), Networking the learner: Computers in education (pp. } \\
\text { 39-48). Boston, MA: Springer. }\end{array}$ \\
\hline 38 & 169 & $\begin{array}{l}\text { Kim, J., Kwon, Y., \& Cho, D. (2011). Investigating factors that influence social presence and learning outcomes in distance higher education. Computers \& Education, } \\
\text { 57, 1512-1520. DOI: http://doi.org/10.1016/j.compedu.2011.02.005 }\end{array}$ \\
\hline 39 & 168 & $\begin{array}{l}\text { Rogers, P., \& Lea, M. (2005). Social presence in distributed group environments: The role of social identity. Behaviour \& Information Technology, } 24,151-158 . \\
\text { doi:10.1080/01449290410001723472 }\end{array}$ \\
\hline 40 & 167 & $\begin{array}{l}\text { Ke, F. (2010). Examining online teaching, cognitive, and social presence for adult students. Computers \& Education, 55, 808-820. DOI: } \\
\text { http://doi.org/10.1016/j.compedu.2010.03.013 }\end{array}$ \\
\hline 41 & 157 & $\begin{array}{l}\text { Leh, A. S. C. (2001). Computer-mediated communication and social presence in a distance learning environment. International Journal of Educational } \\
\text { Telecommunications, 7,109-128. Retrieved from https://www.learntechlib.org/p/8470 }\end{array}$ \\
\hline 42 & 154 & $\begin{array}{l}\text { de Bruyn, L. L. (2004). Monitoring online communication: can the development of convergence and social presence indicate an interactive learning environment? } \\
\text { Distance Education, 25(1), 67-81. DOI: http://dx.doi.org/10.1080/0158791042000212468 }\end{array}$ \\
\hline 43 & 149 & $\begin{array}{l}\text { Caspi, A., \& Blau, I. (2008). Social presence in online discussion groups: Testing three conceptions and their relations to perceived learning. Social Psychology of } \\
\text { Education, 11(3), 323-346. DOI: http://dx.doi.org/10.1007/s11218-008-9054-2 }\end{array}$ \\
\hline 44 & 140 & Tu, C.-H. (2002). The impacts of text-based CMC on online social presence. Journal of Interactive Online Learning, 1(2), 1-24. doi:10.2224/sbp.2007.35.10.1399 \\
\hline 45 & 136 & $\begin{array}{l}\text { Borup, J., West, R. E., \& Graham, C. R. (2012). Improving online social presence through asynchronous video. Internet and Higher Education, 15(3), 195-203. DOI: } \\
\text { http://doi.org/10.1016/j.iheduc.2011.11.001 }\end{array}$ \\
\hline
\end{tabular}




\begin{tabular}{|c|c|c|}
\hline 46 & 135 & $\begin{array}{l}\text { Cobb, S. C. (2009). Social presence and online learning: A current view from a research perspective. Journal of Interactive Online Learning, 8(3), 241-254. Retrieved } \\
\text { from http://www.ncolr.org/jiol/issues/pdf/8.3.4.pdf }\end{array}$ \\
\hline 47 & 133 & $\begin{array}{l}\text { Swan, K. (2003). Developing social presence in online course discussions. In S. Naidu (Ed.), Learning \& Teaching with Technology: Principles and Practices (pp. } \\
\text { 136-153). Sterling, VA: Kogan Page. }\end{array}$ \\
\hline 48 & 132 & $\begin{array}{l}\text { Lowenthal, P. R. (2009). The evolution and influence of social presence theory on online learning. In T. T. Kidd (Ed.), Online education and adult learning: New } \\
\text { frontiers for teaching practices (pp. 124-139). Hershey, PA: IGI Global. }\end{array}$ \\
\hline 49 & 119 & $\begin{array}{l}\text { Annand, D. (2011). Social presence within the community of inquiry framework. International Review of Research in Open and Distributed Learning, } 12(5), 40-56 . \\
\text { Retrieved from http://www.irrodl.org/index.php/irrodl/article/view/924/1855 }\end{array}$ \\
\hline 50 & 113 & $\begin{array}{l}\text { DeSchryver, M., Mishra, P., Koehleer, M. \& Francis, A. (2009). Moodle vs. Facebook: Does using Facebook for Discussions in an Online Course Enhance Perceived } \\
\text { Social Presence and Student Interaction? In I. Gibson, R. Weber, K. McFerrin, R. Carlsen \& D. Willis (Eds.), Proceedings of Society for Information Technology \& } \\
\text { Teacher Education International Conference } 2009 \text { (pp. 329-336). Chesapeake, VA: Association for the Advancement of Computing in Education (AACE). }\end{array}$ \\
\hline
\end{tabular}

